\title{
EFFECT OF SERVICE QUALITY AND BRAND TRUST ON CUSTOMER SATISFACTION AND CUSTOMER LOYALTY PERTAMINA HOSPITAL BALIKPAPAN
}

\author{
Lenny Meitha Wulur ${ }^{1)}$ Theresia Militina $^{2)}$ Gusti Noorlitaria Achmad ${ }^{3)}$ \\ Department of Management, University of Mulawarman. Jalan Tanah Grogot No. 1, Samarinda, East Kalimantan \\ 75119, Indonesia. \\ E-mail: lennywulurrspb@gmail.com
}

\begin{abstract}
:
This research was conducted by Lenny titled "The Effect of Service Quality and Brand Trust on Customer Satisfaction and Customer Loyalty Balikpapan Pertamina Hospital" under the guidance of Prof. Dr. Theresia Militina, M.Siand Dr. Gusti Noorlitaria. A., SE., MM. This study aimed to analyze the influence of service quality and brand trust to customer satisfaction and customer loyalty. The sampling method used in this study is nonprobability Sampling. The sample used in this study were a total of 110 respondents. Analysis of the data used in this study is Partial Least Square with the help of software SmartPLS3.0. This research result shows: (1) Service Quality (X1) positive and significant impact on Customer Satisfaction (Y1), (2) Brand Trust (X2) positive and significant impact on Customer Satisfaction (Y1), (3) Service Quality (X1) positive and significant impact on Customer Loyalty (Y2), (4) Brand Trust (X2) has positive effect but not significant to Customer Loyalty (Y2), (5) Customer Satisfaction (Y1) positive and significant impact on Customer Loyalty (Y2).
\end{abstract}

Keywords : Service Quality, Brand Trust, Customer Satisfaction and Customer Loyalty

\section{Introduction}

Currently very rapid business growth which led to competition between companies, so companies are in demand to provide services beyond customer expectations. Similarly, the Hospital (RS), RS competitive competition for open market policy in the medical services industry Kim et al., (2008),

Advances in scienceand technology has increased public awareness of the importance of health and healthy lifestyles. Maintaining the health or when disease, people need a good service in the field of health. Hospital as a medical institution that is engaged in services, where the main product is a hospital medical services that include treatment, care, optimize health and wellbeing of the patients and providing health education to the community.

Quality of care is important and needs attention because it will be perceived by consumers as consumers get services. Health care providers are expected to delight customers with the best services.

Konsumenpada trust the brand (brand trust) is defined as the desire of consumers to entrust to a brand with all the possible risks faced because of expectations that are expected to have a positive result (Lau and Lee 1999: 344), Some researchers developing the image of high-quality hospitals and consumer confidence may affect consumer decisions (Stambaugh, 2003) and the development of loyalty through imaging (Corstjens et al., 2000 and Bonfrer et al., 2001), Sethuraman (1995) conclude the influence perceptions of quality (quality perception) and the consistency of quality (quality consistency) of the image of the hospital with the desires for the brand (brand purchaseintention) consumer confidence in the brand hospitalthe hospital is one of the keys to success in improving customer satisfaction and maintain customer loyalty in the face 
of competition.Therefore, it needs to be re-examined, especially in brand trust polyclinics Outpatient in Poli Disease Balikpapan Pertamina Hospital.

Consumer satisfaction is a state that is being experienced by a person after he suffered an action or the result of actions to meet expectations. So satisfaction is a fusion between expectation and perception of the act or result of the action. Consumer satisfaction is what will help in forming a loyal customer.

Loyalty is a key to success that must be built by the company in winning the competition. According Reicheld and Sasser in Suhartanto (2000: 5), Argued that the 5\% increase in customer loyalty can increase profits by $25 \%$ to $85 \%$, and $60 \%$ increase in sales to new customers is a top recommendation to the company's loyal customers.

This study was motivated from previous studies of the Quality of Service, Image and Loyalty Consumers who find differences on the effect of Service Quality on customer satisfaction and loyalty in the hospital industry. Bei and Chiao (2001)recommends in his study that further investigation of the influence of tangible and ingitangible in Service Quality on customer satisfaction and loyalty. In respect of this, the researcher adds another variable that is Brand Trust. This study will also follow up the previous research in examining the impact of service quality in the hospital industry to different contexts(Babakus \& Mangold, 1992: Wu.2011) namely in Indonesia by Hospital Type C.

Pertamina Balikpapan has 3 medical specialist in the practice also in outpatient unit. Polyclinic Internal Medicine has integrated diabetes clinical facilities and endoscopy are handled directly with specialists, clinicians, nurses and dietitians certified. With the increasing knowledge and training that is often followed by a specialist in internal medicine and good marketing, it is not surprising clinic's disease in each visit by the patient. But good service quality does not necessarily give satisfaction to the patient. Understanding these factors will be taken into consideration Balikpapan Pertamina Hospital management to improve service quality by adding a specialist Medicine.

\section{Literature review}

\section{Service Quality}

According toLupiyoadi (2001) stated that the overall service quality is the traits and characteristics of a product or service in terms of kemempuan to meet the needs that have been determined, while according to Sembiring et al (2014), Service quality is to provide perfect service performed by the service providers in meeting the needs and desires of the precision konsumenserta penyaampaiannya to offset the customer's expectations.

Ratnasari and Aksa (2011: 107), Quality of service is how far the difference between reality and expectations of customers for services received / obtained.

Zeithaml et al. (2006: 19) Quality of service is the level difference between customer expectations or desires and their perceptions.

According toKotler and Keller (2009) Consumers are an important asset in determining the development of service quality within the company so that the resulting dimensions in service quality, namely:
1. Reliability,
2. responsiveness,
3. assurance,
4. emphaty,
5. tangible, 


\section{Brand Trust}

Lau and Lee (1999: 344) Trust in the brand is a consumer desire to believe in the brands that are exposed to a risk and hope that the brand will lead to positive results.

Ferrinadewi (2008: 148) Confidence in the brand is based on experience with the brand will be a source for consumers for the creation of trust in the brand and this experience will affect consumers in the evaluation of consumption, use of, or the satisfaction of direct and indirect contact with the brand.

Based onLau and Lee (1999)Confidence in the brand has many aspects that guide consumers in making purchasing decisions. There are three indicators, namely:

1. brand Characteristic

2. Company Characteristic

3. Consumer Brand Characteristic

\section{Consumer satisfaction}

Definition of consumer satisfaction byKotler (2014: 150), Satisfaction konsumensebagai feeling happy or disappointed someone to a product after he compared the results / achievements of the product is thinking about product performance or results expected.

Barnes (2003: 64)Customer satisfaction is the response on the fulfillment of their needs. It means that some sort of privilege appraisal of goods or services or goods / services itself, providing a level of comfort associated with the fulfillment of needs, including meeting the needs below expectations or fulfilling the needs exceed customer expectations.

According toTjiptono (2011) Consumer satisfaction has four indicators, namely:

1. Feeling happy for the purchase of

2. Always make a purchase

3. The right shopping choices

4. Recommend

\section{Consumer loyalty}

Kotler and Keller (2009: 138) defines loyalty as strongly held commitment to make another purchase or subscribe to a particular product or service again in the future although there penguruh situation and marketing efforts that could potentially lead to the transition behavior.

According toGriffin (2010: 04) loyalty is A customer is said to be loyal or disloyal if the customer indicates the purchasing behavior regularly or there is a condition which requires customers to buy at least two times within a certain time interval.

Consumer loyalty is customer loyalty against Pertamina Hospital Balikpapan is shown with a positive attitude toward the brand and purchase it in the future indicatorsGriffin (2011):

1. Make repeat purchases.

2. Suggest to a colleague.

3. Buy another product.

4. Shows traction immunity from similar products of competitors.

\section{The influence of service quality on customer satisfaction}

Ratnasari and Aksa (2011: 107), Quality of service is how far the difference between reality and expectations of customers for services received / obtained. Research conductedSetiawan \& Suyuti (2017), Gecti \& Zengin (2013) and Ashraf et al. (2018)explains that service quality affects customer satisfaction. Based on the results of theoretical study and the results of empirical studies it can be arranged or $\mathrm{H} 1$ second allegation is: 
International Journal of Economics, Business and Accounting Research (IJEBAR)

Peer Reviewed - International Journal

Vol-4, Issue-1, 2020 (IJEBAR)

E-ISSN: 2614-1280 P-ISSN 2622-4771

https://jurnal.stie-aas.ac.id/index.php/IJEBAR

\section{H1: Service Quality positive and significant impact on customer loyalty.}

The influence of service quality on customer loyalty

Zeithaml et al. (1900: 19)Quality of service is the level difference between customer expectations or desires and their perceptions. Research conductedSembiring et al. (2014), Darmawan et al. (2017) and Asmarani (2015)explains that service quality affects customer loyalty. Based on study results of empirical studies it can be arranged $\mathrm{H} 2$ in this study are:

H2: Service quality and significant positive effect on customer loyalty.

\section{Effect of brand trust on customer satisfaction}

Lau and Lee (1999: 344)Trust in the brand is a consumer desire to believe in the brands that are exposed to a risk and hope that the brand will lead to positive results. Research conductedAhmad \& Hag (2014), Kiyani et al. (2012)and Arinto et al. (2016)explains that brand trust affects customer satisfaction. Based on study results of empirical studies it can be arranged H3 in this study are:

\section{H3: Brand trust positive and significant impact on customer satisfaction.}

\section{Effect of brand trust on customer loyalty}

Ferrinadewi (2008: 148)Confidence in the brand is based on experience with the brand will be a source for consumers for the creation of trust in the brand and this experience will affect consumers in the evaluation of consumption, use of, or the satisfaction of direct and indirect contact with the brand. Research conductedAndervazh et al. (2013), Upamannyu (2013) and Ahmed (2013)explains that brand trust effect on customer loyalty. Based on study results of empirical studies it can be arranged $\mathrm{H} 4$ in this study are:

H4: Brand trust positive and significant impact on customer loyalty.

\section{The influence of customer satisfaction on customer loyalty}

Consumer satisfaction accordingKotler (2014: 150), Satisfaction konsumensebagai feeling happy or disappointed someone to a product after he compared the results / achievements of the product is thinking about product performance or results expected. Research conductedMudasar et al. (2012), Chiguvi \& Gurowo (2015) and Al-msallam (2015)explains that influence consumer satisfaction on consumer loyalty. Based on study results of empirical studies it can be arranged H5 in this study are:

H5: Consumer satisfaction and significant positive effect on loyalty

Based on the hypothesis that the development has been created it can be arranged framework concept as follows:

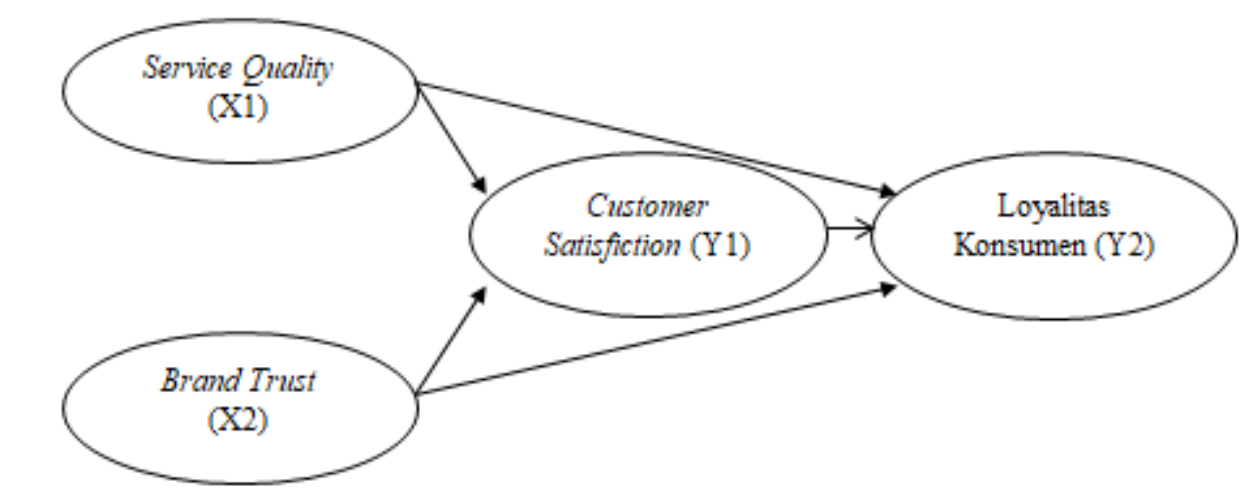


International Journal of Economics, Business and Accounting Research (IJEBAR)

Peer Reviewed - International Journal

Vol-4, Issue-1, 2020 (IJEBAR)

E-ISSN: 2614-1280 P-ISSN 2622-4771

https://jurnal.stie-aas.ac.id/index.php/IJEBAR

\section{Research methods}

\subsection{Population and Sample}

\section{Population}

The study population was all communities Balikpapan being nor ever decide medical treatment at Pertamina Hospital Balikpapan.

\section{Samples}

Sampling in this peneitian using techniques nonprobability ie sampling techniques that do not provide equal opportunity for every member of the population to be selected into the sample (Sugiono, 2013: 120).

As for the conditions specified in the determination of the samples used in this study are: a. Age of the respondents in this study is a minimum of 23-55 years because at this age the respondent has been able to understand and already have an income, so that it can decide to choose treatment at Pertamina Hospital Balikpapan.

b. Respondents are Balikpapan communities that are and have treatment at Pertamina Hospital Balikpapan

\subsection{Instruments and Research Sites}

Researchers should determine research instruments, ie everything related to the research data collection process. Arikunto (2010: 265) states that "a research instrument is an invaluable tool for researchers in collecting data". This research was conducted in East Kalimantan Balikpapan with the goal of consumer Balikpapan Pertamina Hospital.

Data collection, a questionnaire given to respondents who "voted" to be filled or answered according to what is done, felt, experienced, or perceived. Questionnaires conducted initial testing of the 30 respondents to determine the validity and reliability of the questionnaire using SPSS application and then proceed with the application of PLS with 110 respondents.

\section{Results and Discussion}

\section{Examination of the feasibility of the model (Goodness of Fit Model)}

Examination of the model can be seen from the value of R2 (R-square). This means that the model can explain phenomena or variations of customer satisfaction and customer loyalty can be explained by the experiential marketing and customer value while the structural models in this study as follows: 
International Journal of Economics, Business and Accounting Research (IJEBAR)

Peer Reviewed - International Journal

Vol-4, Issue-1, 2020 (IJEBAR)

E-ISSN: 2614-1280 P-ISSN 2622-4771

https://jurnal.stie-aas.ac.id/index.php/IJEBAR

\section{Structural Model Image}

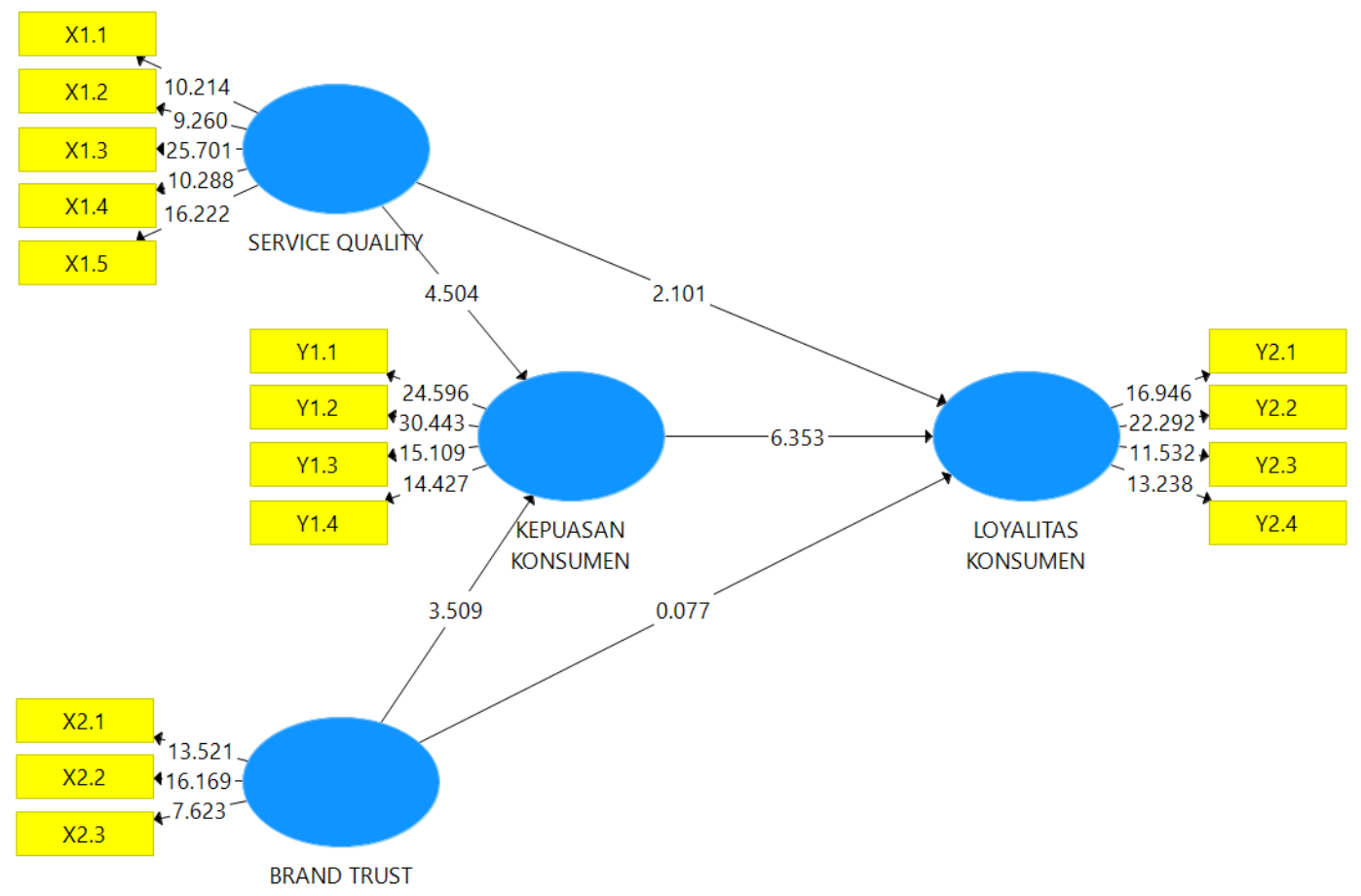

Table R - square

\begin{tabular}{|c|c|c|}
\hline No. & Variables & R-Square \\
\hline 1. & Satisfaction & 0.683 \\
\hline 2. & Consumer loyalty & 0.723 \\
\hline
\end{tabular}

Based on the R-square value obtained by variable customer loyalty by 0.723 . This value is clear that customer loyalty can be explained by the service quality and brand trust of $72.3 \%$. While the other $27.7 \%$ is explained by other variables outside studied. Similarly, the variable gain satisfaction R-Square value of 0.683 means of satisfaction can be explained by the service quality, brand trust and satisfaction of $68.3 \%$. While the other $31.7 \%$ is explained by other variables outside studied.

\section{Hypothesis testing}

In the smart-PLS 3.0 program to determine whether a significant effect relationship or not is to review the value of T-Statistic value fault tolerance of 5\%. The relationship is said to be significant if niilai T-Statistic> 1.96, or it could be through the P-value with the value must be $<0.05$.

The results of hypothesis testing can be seen in the table below:

Table Total effect

\begin{tabular}{|c|l|r|r|r|r|r|}
\hline No. & \multicolumn{1}{|c|}{ variables } & $\begin{array}{c}\text { Original } \\
\text { Sample }\end{array}$ & $\begin{array}{c}\text { sample } \\
\text { Mean }\end{array}$ & $\begin{array}{c}\text { Standard } \\
\text { Deviation }\end{array}$ & $\begin{array}{c}\text { T - } \\
\text { Statistics }\end{array}$ & $\begin{array}{c}\boldsymbol{P} \\
\text { Values }\end{array}$ \\
\hline 1. & $\begin{array}{l}\text { brand Trust } \rightarrow \\
\text { Customer }\end{array}$ & 0.492 & .484 & .090 & 5.487 & 0,000 \\
\hline
\end{tabular}


International Journal of Economics, Business and Accounting Research (IJEBAR)

Peer Reviewed - International Journal

Vol-4, Issue-1, 2020 (IJEBAR)

E-ISSN: 2614-1280 P-ISSN 2622-4771

https://jurnal.stie-aas.ac.id/index.php/IJEBAR

\begin{tabular}{|c|l|r|r|r|r|r|}
\hline & Satisfaction & & & & & \\
\hline 2. & $\begin{array}{l}\text { brand Trust } \rightarrow \\
\text { Consumer Loyalty }\end{array}$ & 0,032 & 0,027 & .101 & .320 & .749 \\
\hline 3. & $\begin{array}{l}\text { Consumer } \\
\text { satisfaction } \rightarrow \\
\text { Consumer loyalty }\end{array}$ & 0.511 & 0.511 & 0.089 & 5.723 & 0,000 \\
\hline 4. & $\begin{array}{l}\text { service Quality } \rightarrow \\
\text { Customer } \\
\text { Satisfaction }\end{array}$ & .379 & 0.385 & 0.087 & 4.357 & 0,000 \\
\hline 5. & $\begin{array}{l}\text { service Quality } \rightarrow \\
\text { Consumer Loyalty }\end{array}$ & 0.361 & 0.364 & 0.094 & 3.861 & 0,000 \\
\hline
\end{tabular}

H1: Stating that the better Service Quality gives 0.379 and significant positive effect will be higher consumer satisfaction with T-statistics value of 4.357 (> 1.96). So that research results are consistent with the first hypothesis stating Service Quality positive and significant impact on customer satisfaction. The first hypothesis is accepted.

H2: Stating that the better Service Quality 0.361 and significant positive effect will be higher consumer loyalty with T-statistic values of 3.861 (> 1.96). So that research results are consistent with the second hypothesis which states Service Quality positive and significant impact on consumer loyalty. Hypothesis 2 received.

H3: Stating that the better the Brand Trust a positive influence 0.492 and significantly higher customer satisfaction with T-statistic values of 5.487 (> 1.96). So the results of this study in accordance with the third hypothesis stating Brand Trust positive and significant impact on customer satisfaction. The third hypothesis is accepted.

H4: Stating that the better the Brand Trust a positive influence 0,032 but no significant impact on the Consumer Loyalty T-statistics value of 0.320 (> 1.96). So this result is not in accordance with the fourth hypothesis stating Brand Trust positive and significant impact on consumer loyalty. Hypothesis 4 is accepted.

H5: Stating that high sermakin consumer satisfaction have a positive influence and significant 0.511 will be higher with the Consumer Loyalty T-statistics value of 5.723 (> 1.96). So the results of this study in accordance with the third hypothesis stating Brand Trust positive and significant impact on customer satisfaction. Hypothesis 5 is accepted.

\section{Effect of Service Quality on Customer Satisfaction}

Based on the analysis and hypothesis testing proved that service quality and significant positive effect on customer satisfaction. This positive coefficient values indicate that the better quality of service, the higher the level of customer satisfaction with the Pertamina Hospital Balikpapan.

The highest scores are loading factor on X1.4.3 indicator that the doctors and nurses at the RSPB poly foster a sense of trust. Consumer perception Balikpapan Pertamina Hospital, doctors and nurses at the RSPB poly successfully fostered a sense of confidence in the consumer.

This research outputs to support research conducted Setiawan \& Suyuti (2017) which shows the service quality has a positive and significant impact on customer satisfaction. Research conducted Darmawan et al. (2017) also showed a positive and significant influence between customer satisfaction. 


\section{Effect of Service Quality on Consumer Loyalty}

The results of the analysis and hypothesis testing proved that service quality but not significant positive effect on customer loyalty. This negative coefficient values indicate that the higher quality of service to the poor it will affect customer loyalty to the Pertamina Hospital Balikpapan.

The lowest scores are on indicators X1.1.4 The RSPB is adequate parking space with loading factor value of 0.631 . These results indicate that consumers are not satisfied with the RSPB parking lot.

This research outputs that do not support research Jimanto \& Kunto (2014)which shows the service quality has a positive and significant impact on customer loyalty. Research conductedNurhadi \& Azis (2017) does not support the results of research also showed a positive and significant influence between customer satisfaction.

\section{Influence of Brand Trust on Customer Satisfaction}

Based on the analysis and hypothesis testing proved that brand trust and significant positive effect on customer satisfaction. This positive coefficient values indicate that the better consumer confidence in the brand, the better the level of customer satisfaction with the Pertamina Hospital Balikpapan.

The highest scores are loading factor on X2.2.1 indicator that I believe the Pertamina Hospital Balikpapan line with my expectations with loading factor value of 0.936 . According to Pertamina Hospital Balikpapan consumers, RS has met the expectations of consumers.

This research outputs to support research conducted Upamannyu (2013)which shows the brand trust has a positive and significant impact on customer satisfaction. Research conductedAndervazh et al. (2013) also showed a positive and significant influence between customer satisfaction.

\section{Influence of Brand Trust on Consumer Loyalty}

Based on the analysis and hypothesis testing proved that brand trust is positive but not significant effect on customer satisfaction. This negative coefficient values indicate that higher consumer confidence in the brand it will affect poor customer loyalty to the Pertamina Hospital Balikpapan.

The lowest scores are on indicators X2.3.3 that I feel that the Pertamina Hospital Balikpapan always provide services that meet customer expectations or the loading factor value of 0.887 . These results show that the consumer is not satisfied with the service RSPB.

This research outputs that do not support research Ahmad \& Hag (2014)which shows the brand trust has a positive and significant impact on customer loyalty. Research conductedAndervazh et al. (2013) does not support the results of research also showed a positive and significant influence between customer satisfaction.

\section{Effect of Customer Satisfaction to Customer Loyalty}

Based on the analysis and hypothesis testing proved that service quality but not significant positive effect on customer loyalty. This negative coefficient values indicate that the higher quality of service to the poor it will affect customer loyalty to the Pertamina Hospital Balikpapan.

The highest scores are loading factor on Y1.1.1 indicator that I am satisfied with the services of doctors in Poli Disease Pertamina Hospital Balikpapan loading factor value of 0.927. 
According to Pertamina Hospital Balikpapan consumers, services provided by a doctor is very satisfying for the consumer.

This research outputs to support research conducted Andervazh et al. (2013)which showed consumer satisfaction has a positive and significant impact on customer loyalty. Research conducted Mohammed et al. (2015) also showed a positive and significant influence between customer satisfaction.

\section{Conclusion and Suggestion \\ Conclusion}

a. service qualitya positive and significant impact on consumer satisfaction Balikpapan Pertamina Hospital. Thus, the third hypothesis is accepted. These results indicate service quality provided to consumers are better able to make an impact on customer satisfaction.

b. service qualitya positive and significant impact on customer loyalty Balikpapan Pertamina Hospital. Thus, the fourth hypothesis is accepted. These results indicate service quality provided to consumers is in accordance with the consumer perception so as to form a Consumer Loyalty.

c. brand trust a positive and significant impact on consumer satisfaction Balikpapan Pertamina Hospital. Thus, the first hypothesis is accepted. These results show that brand trust is built by Pertamina Hospital Balikpapan is able to form a trustworthy brand in accordance perceived by consumers that have an impact on customer satisfaction.

d. brand trust affect positively but not significant to consumer loyalty Balikpapan Pertamina Hospital. Thus, the second hypothesis is rejected. These results show that brand trust is built by Pertamina Hospital Balikpapan is good but has not been able to increase customer loyalty.

e. Customer satisfaction and significant positive effect on consumer loyalty Balikpapan Pertamina Hospital. Thus, the fifth hypothesis is accepted. These results suggest that perceived consumer satisfaction by Pertamina Hospital Balikpapan able to increase customer loyalty.

\section{Suggestion}

a. Consumer satisfaction established by the Service Quality assurance is mainly indicator (X1.3), should be the focus of consideration Balikpapan Pertamina Hospital to be able to retain menimbukan Service Quality Satisfaction Consumers. keep paying attention to other indicators, namely, Responsiveness Tangible, Reliability, and Empathy.

b. Consumer loyalty is influenced by mainly indator Service Quality assurance indicators, should be the focus of consideration Balikpapan Pertamina Hospital to be able to retain menimbukan Service Quality Satisfaction Consumers. keep paying attention to other indicators, namely, Responsiveness Tangible, Reliability, and Empathy.

c. Variable Brand Trust for each indicator, the Consumer Brand Characteristic,

d. Company CharacteristicAnd Brand Characteristic. Brand Consumer seen that the indicator Characteristic is the greatest value, meaning that it must remain a concern the RSPB to obtain customer satisfaction.

e. Variable Brand Trust for each indicator, the Consumer Brand Characteristic, Characteristic Company and Brand Characteristic. Visible been unable to form or causing Consumer Loyalty. RSPB parties should seek to explore other indicators of Brand Trust can increase consumer loyalty.

f. Consumer satisfaction Consumer Loyalty cause or form can be maintained RSPB RSPB parties and seeks to increase consumer exceeds expectations. 
International Journal of Economics, Business and Accounting Research (IJEBAR)

Peer Reviewed - International Journal

Vol-4, Issue-1, 2020 (IJEBAR)

E-ISSN: 2614-1280 P-ISSN 2622-4771

https://jurnal.stie-aas.ac.id/index.php/IJEBAR

g. For further research can use variables or other indicators that have not been studied in this research.

\section{References}

Ahmed (2014)Effect of brand trust and customer satisfaction on brand loyalty in Bahawalpur. Journal of Sociological Research ISSN 1948-5468 2014, Vol. 5, No. 1

Arianto (2016) Effect of Customer Satisfaction, Brand Trust and Customer Feedback To Customer Loyalty On Car Company Suzuki. Al-Qardh Journal, Vol. 1, 5

Arikunto, S. (2013). Management Research (12th ed.). Rineka Reserved.

Barker, C., Pistrang, N., \& Elliott, R. (2015). Research Methods in Clinical Psychology: An Introduction for Students and Practitioners, 3rd Edition. Wiley-Blackwell.

Belaid, S., \& Behi, AT (2011). The role of attachment in building consumer-brand relationships: An empirical investigation in the utilitarian consumption context. Journal of Product and Brand Management, 20 (1), 37-47. https://doi.org/10.1108/10610421111108003

Chaudhuri, A., \& Holbrook, MB (2003). The Chain of Effects from Brand Trust and Brand Affect to Brand Performance: The Role of Brand Loyalty. Journal of Marketing, 65 (2), 8193. https://doi.org/10.1509/jmkg.65.2.81.18255

Chen, S., Chen, X., Cheng, Q., \& Shevlin, T. (2010). Are family firms more aggressive tax than non-family firms? Journal of Financial Economics, 95 (1), 41-61. https://doi.org/10.1016/j.jfineco.2009.02.003

Delgado-Ballester, E., \& Munuera-Alemán, JL (2005). Brand trust does matter to brand equity? Journal of Product and Brand Management, 14 (3), 187-196. https://doi.org/10.1108/10610420510601058

Ferrinadewi, E. (2008). Brand and consumer psychology: implications for marketing strategies. Yogyakarta: Graha Science.

Ghozali, I., \& Latan, H. (2014). Partial Least Square: Concepts, Methods \& Applications Using Warppls Program 4.0 (2nd ed.). Undip.

Giese, JL, \& Cote, JA (2002). Defining consumer satisfaction by Giese. Academy of Marketing Science Review, 2000 (1).

Griffin, E. (2011). A First Look At Communication Theory (8th Ed.). Mc-Graw Hill.

Gurviez, P., \& Korchia, M. (2003). Test of a consumer-brand relationship models Including trusts and three consequences. Thirtieth International Research Seminar in Marketing, (June), 20.

Jeong, Y., \& Lee, Y. (2010). A study on the consumer satisfaction and loyalty of furniture Purchaser in on-line shop. Asian Journal on Quality, 11 (2), 146-156. https://doi.org/10.1108/15982681011075952

Jimanto \& Kunto (2014) Effect of Service Quality on Customer Loyalty With Customer 
Satisfaction As an intervening variable Retail Theaters On The Premiere Surabaya. Marketing Management Program, Universitas Kristen Petra Jl. Siwalankerto 121-131, Surabaya, E-mail: m36410030 @ john.petra.ac.id; kunto_ys@ peter.pet ra.ac.id

Jogiyanto. (2011). Business research methodology. (BPFE Yogyakarta, Ed.) (4th Ed.). BPFEYogyakarta.

Kiyani et al. (2012) The Relationship Between Brand Trust, Customer Satisfaction And Customer Loyalty. (Evidence From Automobile Sector Of Pakistan). Interdisciplinary Journal of Contemporary Research In Business Vol 4, No. 1. ijcrb.webs.com

Kotler, P., \& Keller, kevin lane. (2009). Marketing Management. (J. Purba, Ed.) (12th ed.). PT.indeks.

Kurnia, wind Fazri. (2013). Influence of Brand Experience, Trust and Customer Satisfaction In Building Loyalty In Users Motorcycles. University of Indonesia.

Ladhari, R., Souiden, N., \& Ladhari, I. (2011). Determinants of loyalty and recommendation: The role of perceived service quality, emotional satisfaction and image. Journal of Financial Services Marketing, 16 (2), 111-124. https://doi.org/10.1057/fsm.2011.10

Lau Geok Theng, \& Lee, sook han. (1999). Consumers' trust in a brand and the link to brand loyalty. Journal of Market Focused Management, 4 (1999), 341-370.

Lupiyoadi, R. (2001). Marketing Management Services (Issue 3). Salemba Four.

Mulyatiningsih, E. (2012). Applied Educational Research Methods. Alfabeta CV.

Nguyen, N., Leclerc, A., \& LeBlanc, G. (2013). The mediating Role of Customer Trust on consumer loyalty. Journal of Service Science and Management, 06 (01), 96-109. https://doi.org/10.4236/jssm.2013.61010

Noor, J. (2011). Research Methodology: Theses, Dissertations, and Scientific. Prenada media group.

Nurhadi \& Aziz (2017)Client Service Quality Impact Consumer Trust and Loyalty. Faculty of Economics, University of Yogyakarta, Indonesia Email: nurhadi.fe@ uny.ac.i d

Pratiwi et al. (2015) The Influence Of Brand Image, Brand Trust And Customer Satisfaction On Brand Loyalty (Case Of Samsung Smartphone). Faculty of Economics and Business, Sam Ratulangi University, Manado 95 115, Indonesia E-mail: 1detha_pratiwi@yahoo.com ; 3fjtumewu@gmail.com

Rai, alok kumar, \& Srivastava, M. (2013). The antecedents of consumer loyalty: An Empirical Investigation in Life Insurance Context. Journal of Competitiveness, 5 (2), 139-163. https://doi.org/10.7441/joc.2013.02.10

Santoso, S. (2002). SPSS Statistics Multivariate. Jakarta: PT Elex Media Gramedia Group Komputinso.

Schiffman, L., \& Kanuk, leslie Lazar. (2004). Consumer Behavior (8th ed.). 
International Journal of Economics, Business and Accounting Research (IJEBAR)

Peer Reviewed - International Journal

Vol-4, Issue-1, 2020 (IJEBAR)

E-ISSN: 2614-1280 P-ISSN 2622-4771

https://jurnal.stie-aas.ac.id/index.php/IJEBAR

Sembiring, inka Janita, Suharyono, \& Kusumawati, A. (2014). Effect of Product Quality and Service Quality Satisfaction Konsumendalam Shaping Consumer Loyalty (Studies in KonsumenMcDonald's MT.Haryono Malang). Annales Pharmaceutiques francaises, 68 (2), 1-10. https://doi.org/10.1080/00423114.2017.1410184

Shah, J., \& Inamullah, HM (2012). The Impact of Overcrowded Classroom on the Academy. International Journal of Research in Commerce, Economics and Management, 2 (6).

Sheth, JN, \& Parvatiyar, A. (1995). The Evolution of Relationship Marketing: A Framework for Analysis. International Business Review, 4 (4), 397-418.

Sugiyono. (2013). Statistics For Research (23rd ed.). CV Alfabeta.

Supranto. (2004). Meaning Multivariate Analysis \& Interpretation (1st ed.). PT Rineka Reserved.

Tjiptono, F. (2011). Brand Strategy Management (1st ed.). CV Andi Offset.

Umar, H. (2011). Thesis and Research Methods for Business Thesis (Issue 2). press eagle.

Vesel, P., \& Zabkar, V. (2009). Managing customer loyalty through the mediating role of satisfaction in the DIY retail loyalty program. Journal of Retailing and Consumer Services, 16 (5), 396-406. https://doi.org/10.1016/j.jretconser.2009.05.002

Walker, H. (2001). The Measurement of Word-of-Mouth Communication and an Investigation of Service Quality and Customer Commitment as Potential antecedents. Journal of Service Research, 4 (1), 60-75.

Zeithaml, VA (2006). Consumer Perceptions of Price, Quality, and Value: A Means-End Model and Synthesis of Evidence. Journal of Marketing, 52 (3), 2. https://doi.org/10.2307/1251446 